\title{
Papain enzyme supported on magnetic nanoparticles: Preparation, characterization and application in the fruit juice clarification
}

\author{
Leila Mosafa a, Majid Moghadam ${ }^{\mathrm{b}, *}$, Mohammad Shahedi a \\ a Department of Food Science, College of Agriculture, Isfahan University of Technology, Isfahan 84156, Iran \\ ${ }^{\mathrm{b}}$ Department of Chemistry, Catalysis Division, University of Isfahan, Isfahan 81746-73441, Iran
}

\section{A R T I C L E I N F O}

\section{Article history:}

Received 16 May 2013

Accepted 19 July 2013

Published 20 October 2013

\section{Keywords:}

Magnetic nanoparticle

Papain

Immobilization

Juice clarification

Enzyme activity

\begin{abstract}
A B S T R A C T
The preparation, characterization, and application of silica-coated magnetic nanoparticles for papain immobilization is reported. Papain was covalently attached onto the (3-chloropropyl)trimethoxysilane-modified silica-coated magnetic nanoparticles. The enzyme-immobilized nanoparticles were characterized by Fourier transform infrared spectroscopy, X-ray powder diffraction, scanning electron microscopy, and vibrating sample magnetometry techniques. Response surface methodology combined with statistical analyses using Minitab were employed to evaluate optimum operating conditions to immobilize papain on the magnetic nanoparticles. The optimum conditions were: temperature $=27.3^{\circ} \mathrm{C}, \mathrm{pH}$ of the enzyme solution $=7.1$, concentration of papain $=3.3 \mathrm{mg} / \mathrm{mL}$, and immobilization time $=10 \mathrm{~h}$. Compared with the free papain, the immobilized papain displayed enhanced enzyme activity, better tolerance to variations in the medium $\mathrm{pH}$ and temperature, improved storage stability, and good reusability. Both the free and immobilized enzymes were effective for the clarification of pomegranate juice.
\end{abstract}

(c) 2013, Dalian Institute of Chemical Physics, Chinese Academy of Sciences. Published by Elsevier B.V. All rights reserved.

\section{Introduction}

In the food industry, papain (EC 3.4.22.2) is commonly used for meat tenderization, protein hydrolysate production, and the clarification of juice and beer. Papain is also used in the baking and dairy industries (in cheese production), and for the extraction of flavor and color compounds from plants [1-3]. Furthermore, papain is used in wound debridement and other medical-related procedures [3].

Enzyme immobilization offers several advantages over free enzymes such as choice of batch or continuous processes, rapid termination of reactions, controlled product formation, ease of enzyme removal from the reaction mixture, enhanced thermal stability, and adaptability to diverse engineered designs [4,5]. To date, papain has been immobilized on various supports such as silica spheres [6], activated charcoal [7], cotton fabric [8], and alginate beads [9].

Immobilization of enzymes onto nanoparticles with a high specific surface area is attractive in promoting efficient catalytic processes. Nanomaterials have many advantages because of their unique size and physical properties [10]. However, nanoparticles are difficult to remove from the reaction solution. To address this issue, researchers have investigated the use of magnetic nanoparticles that would be easily recovered under an applied magnetic field $[5,11]$. Among various magnetic nanoparticles, magnetite $\left(\mathrm{Fe}_{3} \mathrm{O}_{4}\right)$ nanoparticles have been considered as ideal candidates for the immobilization of enzymes in view of their multifunctional characteristics such as small size, superparamagnetism, low toxicity, and most importantly, their selective separation property of immobilized enzymes from the reaction mixture $[5,12]$.

However, magnetic nanoparticles are very sensitive to oxi-

\footnotetext{
* Corresponding author. Tel: +98-311-7932712; Fax: +98-311-6689732; E-mail: moghadamm@sci.ui.ac.ir DOI: 10.1016/S1872-2067(12)60663-9 | http://www.sciencedirect.com/science/journal/18722067 | Chin. J. Catal., Vol. 34, No. 10, October 2013
} 
dation and agglomeration because of their high chemical reactivity and large specific surface area. These issues can be addressed by directly coating nanoparticles with thin oxide layers, however, resulting in drastic changes in the particle properties. Hence, to preserve their specific magnetic properties while inhibiting nanoparticle oxidation and agglomeration, encapsulation has been proposed as an alternative method. The use of silica, as a host for encapsulating nanoparticles, has attracted considerable attention because of its low cytotoxicity, ease of surface modification, ease of interparticle interactions control, and high stability under aqueous conditions [12].

Immobilization, through strong covalent bonding, is known to effectively eliminate or significantly reduce the leakage of protein enzyme [5]. Glutaraldehyde [13], thionyl chloride [14], and epoxy groups [3] have been used for the covalent immobilization of papain onto magnetic nanoparticles.

In the present study, magnetite nanoparticles were first synthesized by co-precipitation. The nanoparticles were then encapsulated within a silica matrix using sol-gel, and the surface of the resulting nanoparticles was modified with (3-chloropropyl)trimethoxysilane to immobilize papain (active enzyme) onto the support. The morphology of the particles was characterized using scanning electron microscopy (SEM). The immobilization of papain was confirmed by Fourier transform infrared spectroscopy (FT-IR). The optimum conditions for immobilization of papain were also investigated. The kinetic properties, thermal stability, pH stability of the immobilized papain, and the extent of enzyme confinement/recovery were also examined. Finally, the activity of the immobilized enzyme for the clarification of pomegranate juice was studied and compared with that of the free enzyme counterpart.

\section{Experimental}

\subsection{Materials}

Papain was obtained from Shanghai Biochemical Reagent Co. Ltd. Bovine serum albumin and tyrosine were purchased from Sigma-Aldrich. Coomassie Brilliant Blue G-250 was purchased from Biochemical Company. Casein, Folin-Ciocalteu reagent, ferric chloride hexahydrate $\left(\mathrm{FeCl}_{3} \cdot 6 \mathrm{H}_{2} \mathrm{O}\right)$, ferrous chloride tetrahydrate $\left(\mathrm{FeCl}_{2} \cdot 4 \mathrm{H}_{2} \mathrm{O}\right)$, (3-chloropropyl)trimethoxysilane, ethanol (96\%), polyvinylpyrrolidone (PVP), trichloroacetic acid, acetone, tetraethyl orthosilicate (TEOS), and toluene were obtained from Merck. Deionized water was used in all experiments.

\subsection{Synthesis of PVP-stabilized magnetite nanoparticles}

Of the various methods available for the synthesis of magnetite nanoparticles [12,15], chemical co-precipitation, as a simple and convenient method [6], was used in this study. $\mathrm{FeCl}_{3} \cdot 6 \mathrm{H}_{2} \mathrm{O}(11.0 \mathrm{~g}$, $40.7 \mathrm{mmol} / \mathrm{L})$ and $\mathrm{FeCl}_{2} \cdot 4 \mathrm{H}_{2} \mathrm{O}$ (4.0 g, 20.35 $\mathrm{mmol} / \mathrm{L})$ were dissolved in water $(80 \mathrm{~mL})$ under vigorous stirring, at $85^{\circ} \mathrm{C}$, under argon. The $\mathrm{pH}$ of the solution was adjusted to 9 using concentrated $\mathrm{NH}_{3} \cdot \mathrm{H}_{2} \mathrm{O}$. After $4 \mathrm{~h}$, the resulting magnetite nanoparticles were washed with water until the $\mathrm{pH}$ of the supernatant was 7. The black nanoparticles were then recovered with a permanent magnet and redispersed in water (80 mL), to which PVP aqueous solution ( $4.5 \mathrm{~mL}, 25.6 \mathrm{~g} / \mathrm{L}$ ) was added. The resulting mixture was stirred for $24 \mathrm{~h}$ at room temperature. The PVP-stabilized magnetite nanoparticles were recovered with aqueous acetone solution $\left(\mathrm{H}_{2} \mathrm{O}\right.$ :acetone $=1: 10$, $\mathrm{v} / \mathrm{v}$ ). The precipitated nanoparticles were washed twice with ethanol then dried under vacuum.

\subsection{Preparation of silica-coated magnetite nanoparticles}

Silica-coated $\mathrm{Fe}_{3} \mathrm{O}_{4}$ nanoparticles were prepared using the sol-gel process [16]. PVP-stabilized magnetite nanoparticles (1.5 g) were dispersed in ethanol (300 mL), to which $\mathrm{NH}_{3} \cdot \mathrm{H}_{2} \mathrm{O}$ $(9 \mathrm{~mL})$ and TEOS (3 mL) were successively added. After stirring for $24 \mathrm{~h}$, the black precipitate was collected with a permanent magnet and rinsed with ethanol three times. The product was dried and stored under vacuum.

\subsection{Synthesis of chloropropyl-functionalized silica-coated magnetite nanoparticles}

The silica-coated magnetite nanoparticles (1.0 g) were first dispersed in dry toluene ( $30 \mathrm{~mL})$, assisted by sonication for $1 \mathrm{~h}$. (3-Chloropropyl)trimethoxysilane $(1.8 \mathrm{~mL}, 10 \mathrm{mmol} / \mathrm{L})$ was then added and the reaction mixture was refluxed for $24 \mathrm{~h}$ under argon. After cooling to room temperature, the product was collected onto a magnet and rinsed twice with dry toluene (100 $\mathrm{mL}$ ) followed by two successive washes with dry acetone (100 $\mathrm{mL}$ ). The obtained particles were then dried under vacuum.

\subsection{Papain immobilization}

The chloropropyl-functionalized magnetite nanoparticles (25 mg) were dispersed in the respective citrate $(2 \mathrm{~mL}, \mathrm{pH}$ 3.0-5.0), phosphate ( $\mathrm{pH} \mathrm{6.0-8.0)} \mathrm{or} \mathrm{carbonate} \mathrm{(} \mathrm{pH} 9$ ) buffer solution, at varying enzyme concentrations $(2-10 \mathrm{mg} / \mathrm{mL})$. The immobilization reaction was carried out at different temperatures $\left(10-50{ }^{\circ} \mathrm{C}\right)$ for a specific contact time (1-9 h). The enzyme-immobilized nanoparticles were magnetically recovered and washed three times with the phosphate buffer solution (50 mmol/L, pH 7). The enzyme-immobilized nanoparticles were stored at $4{ }^{\circ} \mathrm{C}$ prior to use. A response surface methodology (RSM), using Minitab Software, was used to optimize the immobilization conditions [9]. The temperature of the immobilization solution, $\mathrm{pH}$ of the enzyme solution, enzyme concentration, and immobilization time were considered as operating (independent) parameters for the immobilization of papain. Their -2 and +2 levels were individually fixed at 10 and $50{ }^{\circ} \mathrm{C}$, pH 3 and 9, enzyme concentration 2 and $10 \mathrm{mg} / \mathrm{mL}$, and immobilization time of 1 and $9 \mathrm{~h}$, respectively. The immobilization amount and activity of enzyme were registered as the two responses/output variables. RSM explores the relationship between the independent variables and the dependent response variables, thereby affording the evaluation of an optimal response. The most popular RSM is the central composite design (CCD) that is commonly employed for establishing a second 
order (quadratic) model for the response variables. To assess the effect of these four independent input parameters on the response variables, CCD was employed to design statistical experiments that consisted of 17 factorial points, eight axial points, and six replicates at the center points, amounting to 31 experiments. Factorial points consist of all possible combinations of $+2,+1,-1$, and -2 levels of factors. The axial points were located at $( \pm \alpha, 0,0,0),(0, \pm \alpha, 0,0),(0,0, \pm \alpha, 0)$, and $(0,0$, $0, \pm \alpha)$, where $\alpha$ is the distance of the axial point from the center. The center points $(0,0,0,0)$ were repeated six times to determine the experimental error and reproducibility of the data.

The set conditions (temperature of the immobilization solution: $30^{\circ} \mathrm{C}$; $\mathrm{pH}$ of the enzyme solution: 6 ; enzyme concentration: $6 \mathrm{mg} / \mathrm{mL}$; and immobilization time of papain: $5 \mathrm{~h}$ ) were considered as the center point. On completion of the 30 experiments, as designed by CCD, and after determination of the enzyme activity and amount of enzyme immobilization under each set of conditions, analysis of variance (ANOVA) was used to assess the best immobilization conditions.

\subsection{Determination of the amount of immobilized enzyme}

The amount of papain immobilized onto the magnetite nanoparticles was determined by measuring the initial and final concentrations of papain in the immobilization medium using the Bradford method [17].

\subsection{Assays of papain activity}

The enzymatic activity of free and immobilized papain was determined using casein as a substrate [18]. A known amount of free or immobilized papain, phosphate buffer solution $(5 \mathrm{~mL}$, $\mathrm{pH} 7$ ), and casein solution ( $1 \mathrm{~mL}, 0.5 \%$ ) were mixed in a glass tube. After enzymatic reaction at $37^{\circ} \mathrm{C}$ for $15 \mathrm{~min}$, under gentle stirring, trichloroacetic acid ( $2 \mathrm{~mL}, 10 \%)$ was added to stop the reaction. The reaction mixture was filtered off. $\mathrm{Na}_{2} \mathrm{CO}_{3}(5 \mathrm{~mL}$, $0.4 \mathrm{~mol} / \mathrm{L})$ and folin $(1 \mathrm{~mL})$ solutions were added to the filtrate $(1 \mathrm{~mL})$. The mixture was incubated at $37{ }^{\circ} \mathrm{C}$ for $15 \mathrm{~min}$. The absorbance of the solution was measured at $680 \mathrm{~nm}$. One unit of enzyme activity is defined as $1 \mu \mathrm{g}$ of tyrosine formed per minute at $37^{\circ} \mathrm{C}$.

The reusability of the immobilized papain was evaluated over 10 successive cycles. The residual activity was measured after each cycle. The amount of enzyme leaching during the successive cycles was also determined: at the end of each catalytic cycle, the immobilized enzyme was removed by a magnet and the amount of enzyme leached was measured by the Bradford method.

\subsection{Determination of optimum activity of the free and immobilized enzyme}

The influence of temperature and solution $\mathrm{pH}$ on the optimum activity of the free and immobilized papain was separately evaluated. In the first instance, the activity of the enzymes following incubation, for $30 \mathrm{~min}$, in a phosphate buffer solution (50 mmol/L, pH 7) was monitored at varying temperatures $\left(20-80{ }^{\circ} \mathrm{C}\right)$. In the second study, the activity of the enzyme after incubation, for $30 \mathrm{~min}$, at a given temperature was measured over a range of $\mathrm{pH} 3-9$. The optimum temperature and $\mathrm{pH}$ for optimal enzyme activity were subsequently determined.

\subsection{Storage stability of the free and immobilized enzyme}

The storage stability of the immobilized and free enzyme was determined by monitoring the enzyme activity following storage at $4{ }^{\circ} \mathrm{C}$ in a phosphate buffer solution $(50 \mathrm{mmol} / \mathrm{L}, \mathrm{pH}$ 7) over a period of $30 \mathrm{~d}$.

\subsection{Determination of kinetic parameters}

Enzyme activity, in the free and immobilized forms, was evaluated using the Michaelis-Menten equation $V=V_{\max }[\mathrm{S}] /\left(K_{\mathrm{m}}\right.$ $+[\mathrm{S}]$ ), where [S] is the substrate concentration, $V_{\max }$ is the maximum reaction rate attained at infinite substrate concentration, and $K_{\mathrm{m}}$ is the Michaelis-Menten constant. The kinetic parameters of the free and immobilized enzyme were determined in the concentration range of $0.004-0.4 \mathrm{mmol} / \mathrm{L}$ casein.

\subsection{Juice clarification studies}

The enzymatic activity of the free and immobilized papain towards the clarification of turbidity was investigated using pomegranate as a model juice. Aliquots of pomegranate juice were poured into glasses and the reaction was initiated by adding $0.5 \%(\mathrm{w} / \mathrm{v})$ of the free or immobilized enzyme. The contents were vigorously shaken and placed in a water bath at $50{ }^{\circ} \mathrm{C}$ and incubated for $1 \mathrm{~h}$. After treatment, the nanoparticles were separated from the reaction solution, using a magnet, or filtered through a Whatman filter paper (No. 1). The respective filtrate solutions were stored at $4{ }^{\circ} \mathrm{C}$ in the dark for up to $14 \mathrm{~d}$. The turbidity of the solution was measured immediately after the clarification treatment (day 0 ), and after 1,7 , and $14 \mathrm{~d}$ of storage at $4^{\circ} \mathrm{C}$.

\subsection{Statistical analysis}

SAS JMP 6 was used for the analysis and modeling of the data by completely randomized design. Significance of the results was established at $p<0.05$. Each datum represents the mean of three independent assays.

\section{Results and discussion}

\subsection{Characterization of nanoparticles}

The morphology of the chloropropyl-functionalized $\mathrm{Fe}_{3} \mathrm{O}_{4}-\mathrm{SiO}_{2}$ nanoparticles was analyzed using $\mathrm{SEM}$, as shown in Fig. 1. The nanospheres show a smooth surface and an average particle size of $38 \mathrm{~nm}$.

The EDX spectra of the nanoparticles and silica-coated nanoparticles are illustrated in Fig. 2. The analyses confirmed the 

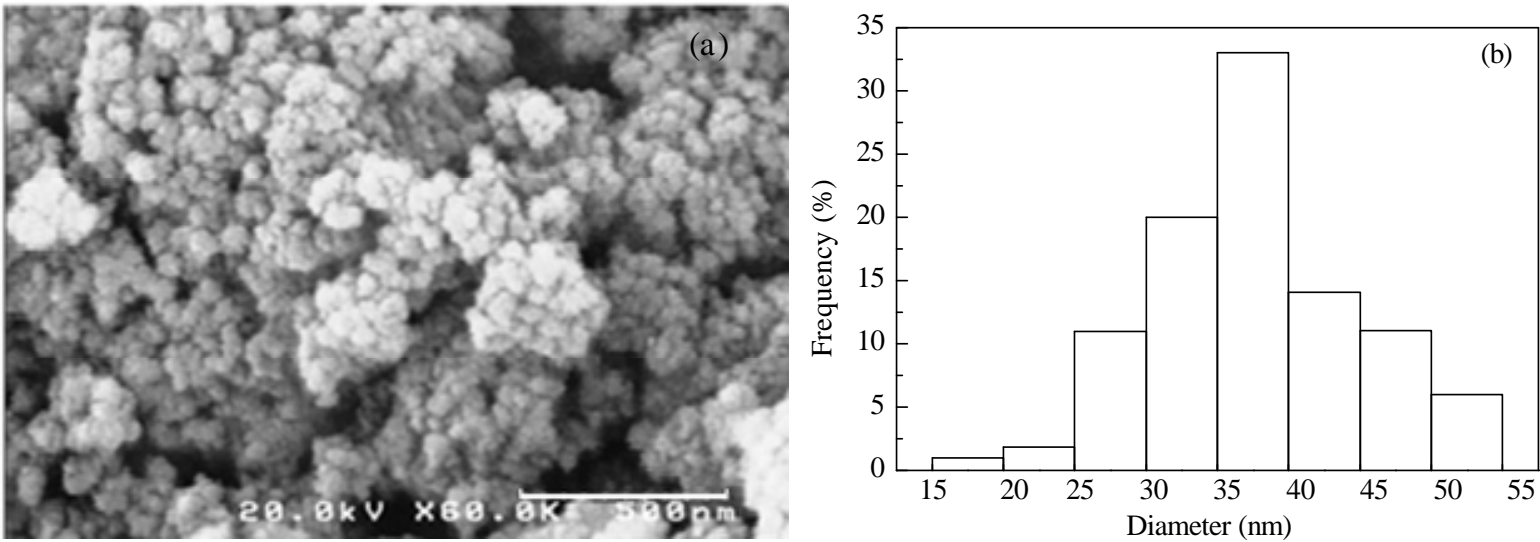

Fig. 1. SEM image (a) and size distribution (b) of the chloropropyl-functionalized $\mathrm{Fe}_{3} \mathrm{O}_{4}-\mathrm{SiO}_{2}$ nanoparticles.

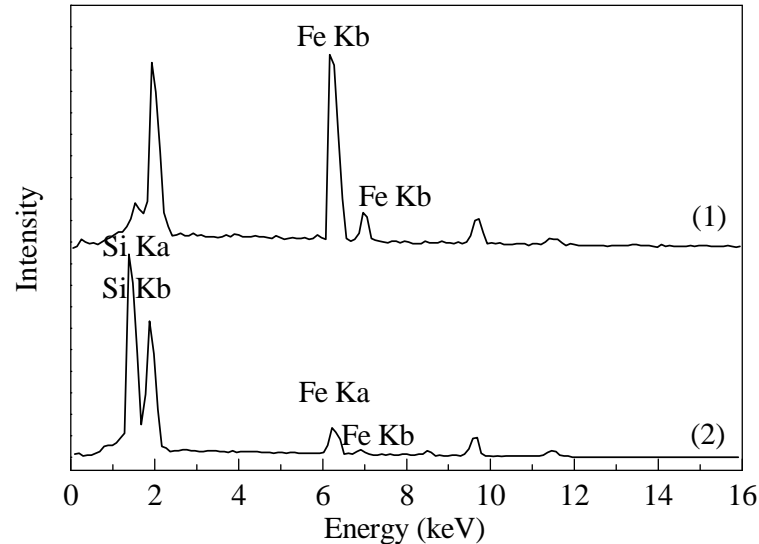

Fig. 2. EDX spectra of magnetite nanoparticles before (1) and after (2) coating with silica.

coexistence of silica and iron, with a Si:Fe atomic mass ratio of 58.6:41.4, thus indicating the successful coating of the magnetite nanoparticles with silica.

FT-IR spectroscopy was used to evaluate the binding of papain onto the chloropropyl-functionalized $\mathrm{Fe}_{3} \mathrm{O}_{4}-\mathrm{SiO}_{2}$ nanoparticles. The spectrum of the nanoparticles, following conjugation with papain (Fig. 3(3)), not only shows characteristic bands of $\mathrm{Fe}_{3} \mathrm{O}_{4}-\mathrm{SiO}_{2}$ at 588 (Fe-0), 798, and $1082 \mathrm{~cm}^{-1}$ (Si-O-Si), but also characteristic peaks of the parent papain at $1650 \mathrm{~cm}^{-1}$ $(-\mathrm{CONH})$ and $1542 \mathrm{~cm}^{-1}(-\mathrm{NH})$. This confirmed the successful immobilization of papain onto the modified nanoparticles.

The magnetic properties of the composite nanospheres were assessed by a vibrating sample magnetometer (VSM). As shown in Fig. 4, the saturation magnetic moments of the chloropropyl-functionalized silica-coated $\mathrm{Fe}_{3} \mathrm{O}_{4}$ nanoparticles before (Fig. 4(1)) and after (Fig. 4(2)) conjugation with papain reached 40 and $32 \mathrm{emu} / \mathrm{g}$, respectively. Both of them showed superparamagnetic behavior that would enable easy recovery of the enzymes from insoluble or larger substrates, even in the presence of solids, under an applied magnetic field. For industrial and practical application, this is an essential attribute for the reutilization of the immobilized enzymes, as biocatalysts, for extended periods of time.
The XRD patterns of the modified magnetite nanoparticles with and without bound papain were recorded. Characteristic peaks of $\mathrm{Fe}_{3} \mathrm{O}_{4}$ at $2 \theta=18.27,30.06,35.42,37.05,43.05,53.39$, 56.94 , and $62.52^{\circ}$ were observed in both samples, thereby indicating that the binding process did not induce any phase change.

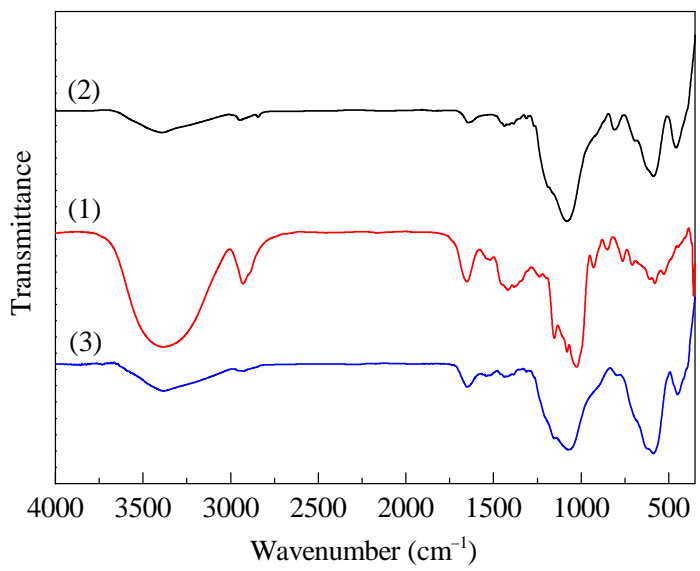

Fig. 3. FT-IR spectra of pure papain (1) and the modified nanoparticles without (2) and with (3) bound papain.

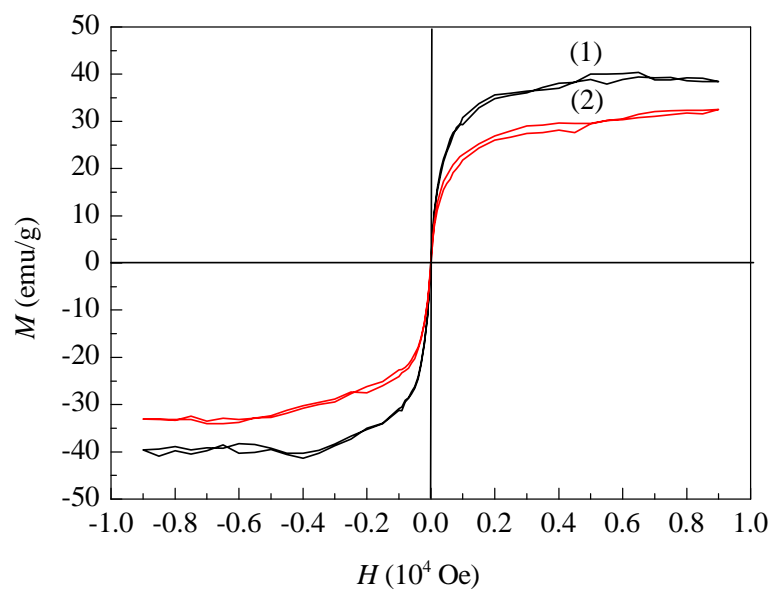

Fig. 4. Magnetization versus magnetic field plots of modified magnetite nanoparticles without (1) and with (2) conjugated papain at $27^{\circ} \mathrm{C}$. 


\subsection{Immobilization of papain}

Optimum conditions for papain immobilization were determined using Minitab Software. The list of experiments (operating conditions) as designed by the RSM and the associated response values for each set of conditions are shown in Table 1. The responses, corresponding to the immobilization amount and activity of enzyme, were fitted with a quadratic model based on the sequential model sum of squares. The final empirical formulae models for both responses, in terms of coded factors, are presented in equations (1) and (2), respectively:

$$
R_{1}=44.97+2.45 C+3.31 B^{2}+2.47 D^{2}+3.01 A C+3.24 A D-
$$

\section{$5.15 C D$}

$$
R_{2}=45.21+5.20 B+9.10 D+7.07 D^{2}-6.41 A B+6.33 A D+
$$
$6.03 B D$

where $R_{1}$ and $R_{2}$ represent immobilization amount of enzyme and the immobilized enzyme activity, respectively, $A$ is the temperature of the immobilization solution, $B$ is the $\mathrm{pH}$ of the enzyme solution, $C$ is the enzyme concentration, and $D$ is the immobilization time.

ANOVA was used to further justify the significance of the parameters on responses based on the $p$-value with $95 \%$ confidence interval. For the immobilization amount of enzyme response, the model terms $C, B^{2}, D^{2}, A C, A D$, and $C D$ were statistically significant as opposed to the terms $A, B, D, A^{2}, C^{2}, A B, B C$, and $B D$. For the enzyme activity response, $B, D, D^{2}, A B, A D$, and $B D$ were statistically significant model terms unlike $A, C, A^{2}, B^{2}$,

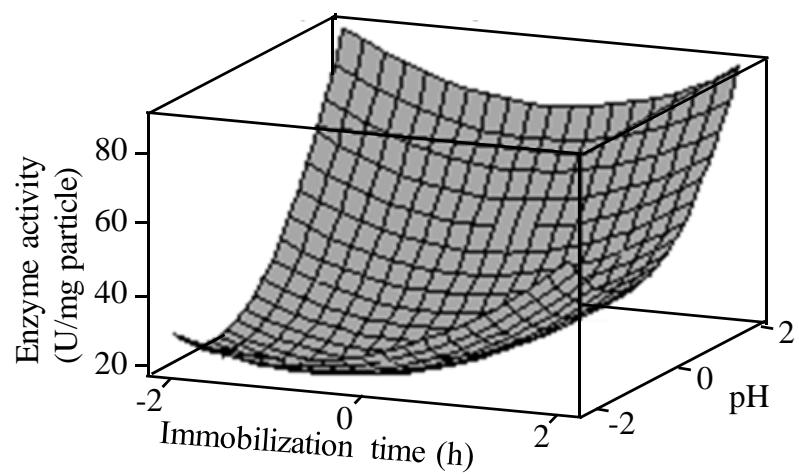

Fig. 5. Effect of $\mathrm{pH}$ and immobilization time on enzyme activity of immobilized papain sample.

$C^{2}, A C, B C$, and $C D$.

The $p$-values showed that parameter $D$ has the greatest impact on the enzyme activity response followed by $B$. Figure 5 shows the three-dimensional response curve, showing the effect of parameters $B$ and $D$ on enzyme activity. The parameters $A$ and $C$ were fixed at zero. At shorter immobilization time, enzyme activity decreases at increasing $\mathrm{pH}$ values whereas at longer immobilization time, enzyme activity increases at increasing $\mathrm{pH}$ values.

The developed models for both responses were validated by the correlation coefficient (i.e., $R^{2}=0.79$ ). The optimized conditions for immobilization of papain onto magnetite nanoparti-

Table 1

\begin{tabular}{|c|c|c|c|c|c|c|c|}
\hline Std. order & Run order & $A\left({ }^{\circ} \mathrm{C}\right)$ & $B$ & $C(\mathrm{mg} / \mathrm{mL})$ & $D(\mathrm{~h})$ & $R_{1}$ & $R_{2}$ \\
\hline 16 & 1 & 40 & 7.5 & 8 & 7 & 59.32 & 88.10 \\
\hline 5 & 2 & 20 & 4.5 & 8 & 3 & 58.00 & 40.90 \\
\hline 24 & 3 & 30 & 6 & 6 & 9 & 52.77 & 82.34 \\
\hline 6 & 4 & 20 & 7.5 & 8 & 3 & 59.40 & 51.92 \\
\hline 14 & 5 & 20 & 7.5 & 8 & 7 & 57.90 & 86.10 \\
\hline 20 & 6 & 50 & 6 & 6 & 5 & 54.09 & 67.57 \\
\hline 7 & 7 & 40 & 4.5 & 8 & 3 & 58.77 & 82.96 \\
\hline 19 & 8 & 10 & 6 & 6 & 5 & 59.60 & 55.80 \\
\hline 29 & 9 & 30 & 6 & 6 & 5 & 50.40 & 47.92 \\
\hline 1 & 10 & 20 & 4.5 & 4 & 3 & 54.70 & 40.78 \\
\hline 9 & 11 & 20 & 4.5 & 4 & 7 & 56.50 & 54.68 \\
\hline 27 & 12 & 30 & 6 & 6 & 5 & 44.50 & 46.67 \\
\hline 13 & 13 & 20 & 4.5 & 8 & 7 & 48.38 & 33.53 \\
\hline 31 & 14 & 30 & 6 & 6 & 5 & 40.00 & 51.40 \\
\hline 23 & 15 & 30 & 6 & 6 & 7 & 54.19 & 66.31 \\
\hline 21 & 16 & 30 & 6 & 2 & 5 & 44.11 & 52.42 \\
\hline 26 & 17 & 30 & 6 & 6 & 5 & 40.20 & 36.65 \\
\hline 15 & 18 & 40 & 4.5 & 8 & 7 & 44.14 & 79.10 \\
\hline 17 & 19 & 30 & 3 & 6 & 5 & 52.49 & 45.40 \\
\hline 8 & 20 & 40 & 7.5 & 8 & 3 & 53.50 & 40.03 \\
\hline 10 & 21 & 20 & 7.5 & 4 & 7 & 53.70 & 62.25 \\
\hline 3 & 22 & 40 & 4.5 & 4 & 3 & 39.90 & 35.03 \\
\hline 2 & 23 & 20 & 7.5 & 4 & 3 & 45.10 & 58.05 \\
\hline 30 & 24 & 30 & 6 & 6 & 5 & 49.90 & 50.01 \\
\hline 28 & 25 & 30 & 6 & 6 & 5 & 46.80 & 40.66 \\
\hline 4 & 26 & 40 & 7.5 & 4 & 3 & 24.10 & 36.03 \\
\hline 12 & 27 & 40 & 7.5 & 4 & 7 & 58.46 & 93.48 \\
\hline 18 & 28 & 30 & 9 & 6 & 5 & 32.00 & 47.67 \\
\hline 11 & 29 & 40 & 4.5 & 4 & 7 & 57.70 & 74.83 \\
\hline 25 & 30 & 30 & 6 & 6 & 5 & 43.00 & 43.16 \\
\hline 22 & 31 & 30 & 6 & 10 & 5 & 48.92 & 71.07 \\
\hline
\end{tabular}

Experimental design and results. 

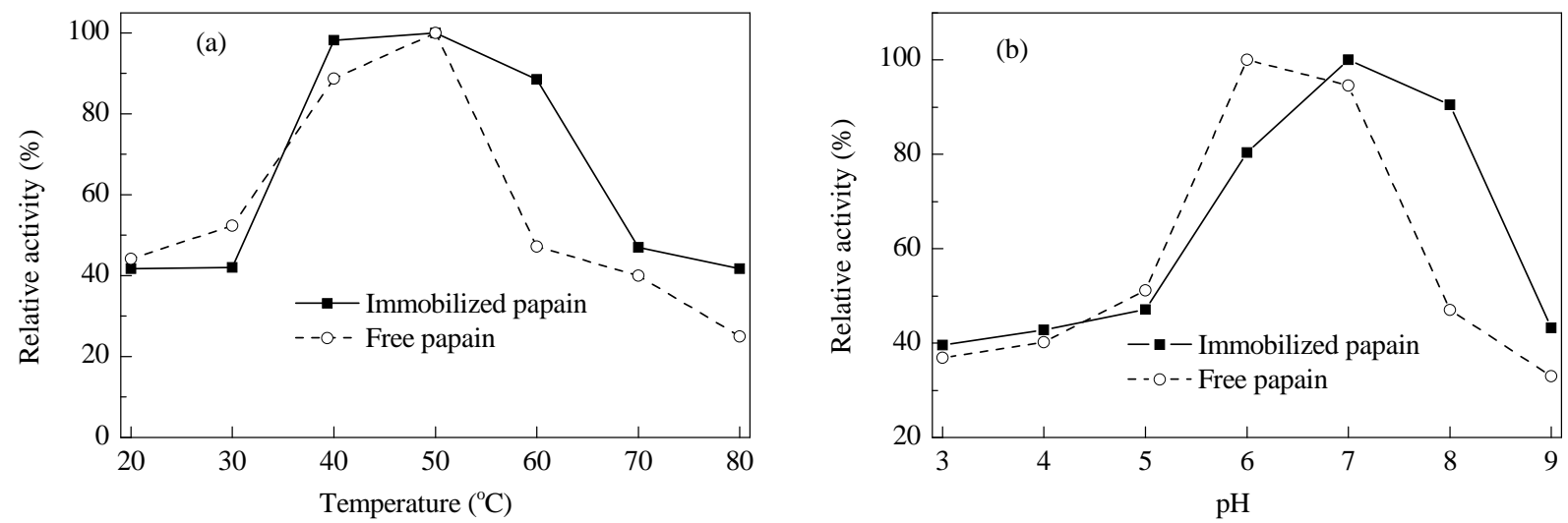

Fig. 6. Thermal (a) and pH (b) stability of the immobilized and free papain.

cles were determined as: temperature of the immobilization solution: $27.3{ }^{\circ} \mathrm{C}$; $\mathrm{pH}$ of the enzyme solution: 7.1; enzyme concentration: $3.3 \mathrm{mg} / \mathrm{mL}$; and immobilization time: $10 \mathrm{~h}$. The optimum immobilization yield was $58.3 \%$.

\subsection{Temperature and $p H$ optimization}

The activity of the free and immobilized papain, at a temperature range of $20-80^{\circ} \mathrm{C}$, is shown in Fig. 6(a). ANOVA analysis indicated that there was a statistically significant difference $(p<0.05)$ between the activity of these two samples. Both forms of enzyme displayed substantial activity enhancements at higher temperatures, reaching an optimum activity at $50{ }^{\circ} \mathrm{C}$. The improvement in enzymatic activity at higher temperatures is due to increased enzyme fixation on the support as a result of reduced autolysis processes, as described by Lei et al. [19].

Figure $6(\mathrm{~b})$ illustrates the dependence of the respective activity of the free and immobilized papain on the solution $\mathrm{pH}$. Likewise, ANOVA analysis indicated a statistically significant difference $(p<0.05)$ between the activity of these two samples. Respective maximum activity of the free and immobilized papain was obtained at optimum $\mathrm{pH}$ values of 6.0 and 7.0. The high adaptability of immobilized papain to an alkaline environment is evidenced by its relatively high activity under such conditions: at $\mathrm{pH} 9.0$, the immobilized papain retained $75 \%$ of its initial activity as opposed to its free counterpart that only preserved 33\% of its original activity. These findings indicate that the covalent bonds between the enzyme and the support are sufficiently stable to resist conformational changes and reduce the rate of the dissociation of the enzyme, even in high ionic strength solutions.

\subsection{Storage stability and catalyst recycling}

The change in activity of the free and immobilized enzymes stored at $4{ }^{\circ} \mathrm{C}$ over a period of $30 \mathrm{~d}$ is shown in Fig. 7. Statistically, there was a significant difference in the storage stability of the two forms of enzyme $(p<0.05)$. The immobilized enzyme displayed improved storage stability, which agreed with a previously reported study [14]. The higher storage stability of the immobilized papain could be attributed to the strong covalent bonds between papain and the support that inhibit dena- turation of the enzyme molecule over a long period of time [20].

Ten consecutive cycles were conducted to assess the reusability of the papain immobilized on $\mathrm{Fe}_{3} \mathrm{O}_{4}-\mathrm{SiO}_{2}$ nanospheres. The residual activity of the immobilized papain following each cycle is shown in Fig. 8. The immobilized papain maintained a relatively high activity (i.e., $\sim 75.15 \%$ ) after six cycles, which slightly decreased to $\sim 40 \%$ after the tenth cycle. It has been suggested that the immobilized enzyme could adopt an optimum conformation during the cycling steps, thereby allowing further activation of the immobilized enzyme [14]. The steady decrease in the enzymatic activity following consecutive cycles can be attributed to enzyme leaching. The amount of enzyme leached after the first and tenth cycles were measured at $\sim 3.7 \%$ and $0.8 \%$, respectively. The actual activity of the leached enzyme after these two cycles was 96.7 and $36.8 \mathrm{U} / \mathrm{mg}$ of enzyme, respectively.

\subsection{Kinetic parameters}

The kinetic parameters of the free and immobilized enzymes were determined from the Lineweaver-Burk plots, using casein $(0.004-0.4 \mathrm{mmol} / \mathrm{L})$ as a substrate. $V_{\max }$ relates to the maximum rate of product formation and $K_{\mathrm{m}}$, which is a measure of the affinity of the enzyme towards the substrate, corresponds to the amount of substrate required to reach half of the maximum velocity. $K_{\mathrm{m}}$ was higher for the immobilized enzyme

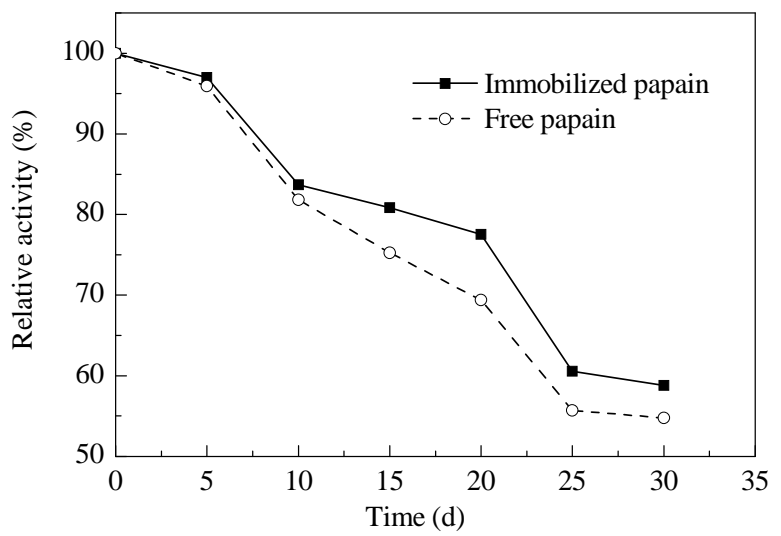

Fig. 7. Storage stability of the immobilized and free papain. 


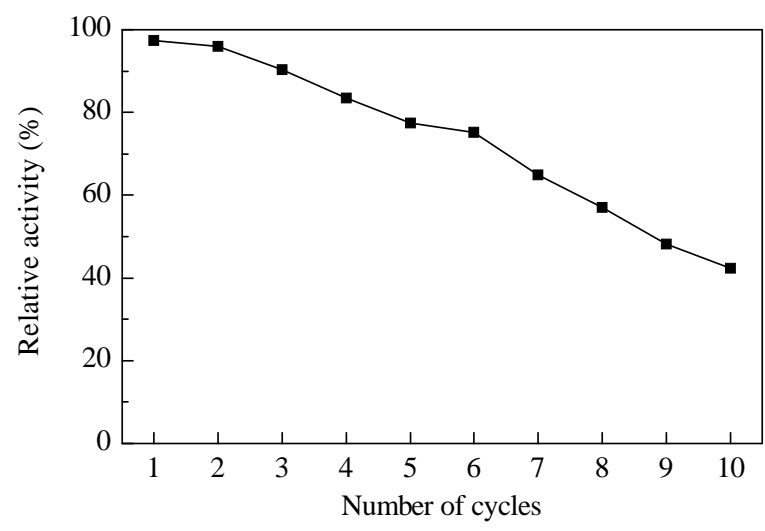

Fig. 8. Reusability tests of the immobilized papain.

(i.e., $0.235 \mathrm{mmol} / \mathrm{L}$ ) when compared with that of the free papain (i.e., $0.199 \mathrm{mmol} / \mathrm{L}$ ), as expected from the study by Bhattacharyya et al. who reported a higher $K_{\mathrm{m}}$ value for papain immobilized on alginate beads. The three-dimensional structure of the support is expected to influence the diffusion properties of the resulting immobilized papain nanospheres, thereby contributing to the resulting $K_{\mathrm{m}}$ values. $V_{\max }$ was unaffected by the immobilization process. Both the free and immobilized enzyme achieved comparable $V_{\max }$ values (i.e., $0.431 \mathrm{mmol}$ $\mathrm{min}^{-1}$ (mg of enzyme) ${ }^{-1}$ and $0.428 \mathrm{mmol} \mathrm{min}^{-1}$ (mg of particles) ${ }^{-1}$, respectively), thus indicating that the immobilized enzyme achieves the same velocity as that of the free enzyme when saturated with the substrate.

\subsection{Effect of enzyme treatment on pomegranate juice turbidity}

The performance of the free and immobilized papain for the clarification of pomegranate juice is herein discussed. The turbidity-reducing effect of either form of the enzymes, after the treatment, at day 0 was statistically significant (Table 2). The turbidity-lowering effect of the protease treatment was maintained until the end of the cold storage period, at day 14. Pinelo et al. [20] proposed that the protease catalyzes the hydrolysis of the proteins in the juice and prevents the formation of complexes between the positively-charged proteins and negatively-charged pectins. The insolubility and turbidity effects, in-
Table 2

Turbidity levels in pomegranate juice samples after treatment with free and immobilized enzyme over a period of $14 \mathrm{~d}$ of cold storage.

\begin{tabular}{lcccc}
\hline Sample & Day 0 & Day 1 & Day 7 & Day 14 \\
\hline Not clarified & $68.5^{\mathrm{a}}$ & $82.1^{\mathrm{a}}$ & $91.7^{\mathrm{a}}$ & $92.5^{\mathrm{a}}$ \\
Clarification with free papain & $29.4^{\mathrm{b}}$ & $42.6^{\mathrm{b}}$ & $43.4^{\mathrm{b}}$ & $44.2^{\mathrm{b}}$ \\
Clarification with immobilized & $30.4^{\mathrm{b}}$ & $43.1^{\mathrm{b}}$ & $43.9^{\mathrm{b}}$ & $44.7^{\mathrm{b}}$ \\
papain & & & &
\end{tabular}

The mean values, denoted with the same superscript letter, within a column are not significantly different using the LSD test at $p<0.05$.

duced by these complexes or complexes, resulting from the association of proteins with cell materials and/or phenolic compounds, could be alleviated under proteolytic actions [21]. Both forms of protease effectively decreased the development of turbidity during cold storage.

\section{Conclusions}

Papain was covalently immobilized on the surface of silica-coated magnetite nanoparticles using (3-chloropropyl)trimethoxysilane as a surface modifier and coupling agent. The diameter of the silica-coated magnetite nanoparticles was estimated at $38 \mathrm{~nm}$ using SEM. FT-IR spectroscopy confirmed the immobilization of papain onto the nanoparticles. The properties of the immobilized enzyme were compared with those of the free enzyme counterpart. In solution, the immobilized papain displayed higher relative activity and stability properties than those featured by the free enzyme. More specifically, the immobilized enzyme showed optimum activity over a wider range of $\mathrm{pH}$ values and temperatures when compared to that of the free enzyme. The storage stability and reusability properties of the immobilized papain were also enhanced. Furthermore, the immobilized enzyme can be easily recovered under an applied magnetic field owing to the magnetic properties of the host matrix.

\section{Acknowledgements}

Financial support from Isfahan University of Technology is gratefully acknowledged.

\section{Graphical Abstract}

Chin. J. Catal., 2013, 34: 1897-1904 doi: 10.1016/S1872-2067(12)60663-9

Papain enzyme supported on magnetic nanoparticles: Preparation, characterization and application in the fruit juice clarification

Leila Mosafa, Majid Moghadam*, Mohammad Shahedi Isfahan University of Technology, Iran; University of Isfahan, Iran

Papain immobilized on silica-coated magnetic nanoparticles was prepared. The performance of the immobilized enzyme for the clarification of pomegranate juice was investigated and compared with that of the free enzyme. The reusability of the immobilized enzyme nanoparticles was also examined.

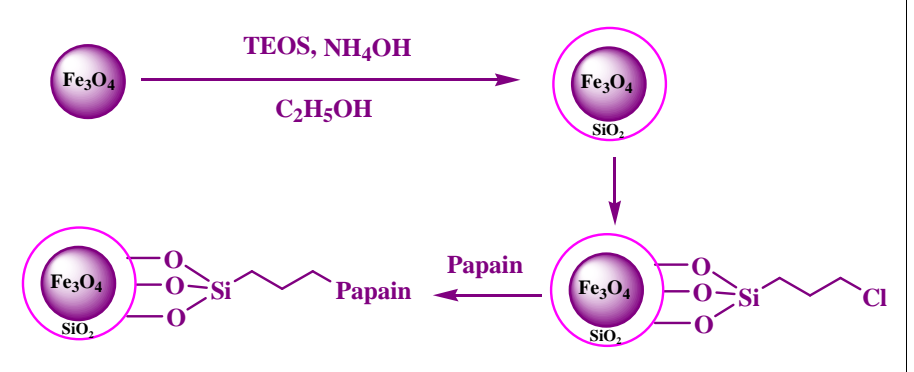




\section{References}

[1] Sumantha A, Larroche C, Pandey A. Food Technol Biotechnol, 2006, 44: 211

[2] Wang M F, Jia C X, Qi W, Yu Q X, Peng X, Su R X, He Z M. Bioresour Technol, 2011, 102: 3541

[3] Bayramoglu G, Senkal B F, Yilmaz M, Arica M Y. Bioresour Technol, 2011, 102: 9833

[4] Prakasham R S, Devi G S, Laxmi K R, Rao C S. J Phys Chem C, 2007, 111: 3842

[5] Ranjbakhsh E, Bordbar A K, Abbasi M, Khosropour A R, Shams E. Chem Eng J, 2012, 179: 272

[6] Zhao Y B, Qiu Z M, Huang J Y. Chin J Chem Eng, 2008, 16: 451

[7] Dutta S, Bhattacharyya A, De P, Ray P, Basu S. J Hazard Mater, 2009, 172: 888

[8] Li F Y, Xing Y J, Ding X. Enzyme Microb Technol, 2007, 40: 1692

[9] Bhattacharyya A, Dutta S, De P, Ray P, Basu S. Bioresour Technol, 2010, 101: 9421
[10] Kim J, Grate J W, Wang P. Chem Eng Sci, 2006, 61: 1017

[11] Liang Y Y, Zhang L M. Biomacromolecules, 2007, 8: 1480

[12] Faraji M, Yamini Y, Rezaee M. J Iran Chem Soc, 2010, 7: 1

[13] Ding L, Yao Z H, Li T, Qiu M P, Yue Q, Chai J. Iran Polym J, 2003, 12: 491

[14] Lei H, Wang W, Chen L L, Li X C, Yi B, Deng L. Enzyme Microb Technol, 2004, 35: 15

[15] Chen X Q, Lam K F, Zhang Q J, Pan B C, Arruebo M, Yeung K L. J Phys Chem C, 2009, 113: 9804

[16] Shokouhimehr M, Piao Y, Kim J, Jang Y, Hyeon T. Angew Chem Int $E d, 2007,46: 7039$

[17] Bradford M M. Anal Biochem, 1976, 72: 248

[18] Bhattacharyya K G, Gupta S S. Chem Eng J, 2008, 136: 1

[19] Lei Z L, Ren N, Li Y L, Li N, Mu B. J Agric Food Chem, 2009, 57: 1544

[20] Pinelo M, Zeuner B, Meyer A S. Food Bioprod Process, 2010, 88: 259

[21] Siebert K J, Carrasco A, Lynn P Y. J Agric Food Chem, 1996, 44: 1997 